\title{
Community structure and functioning in intertidal rock pools: effects of pool size and shore height at different successional stages
}

\author{
G. M. Martins ${ }^{1,2,4, *}$, S. J. Hawkins ${ }^{1}$, R. C. Thompson ${ }^{2}$, S. R. Jenkins ${ }^{1,3}$ \\ ${ }^{1}$ Marine Biological Association, Citadel Hill, Plymouth PL1 2PB, UK \\ ${ }^{2}$ Marine Biology and Ecology Research Group, University of Plymouth, Plymouth PL4 8AA, UK \\ ${ }^{3}$ School of Ocean Sciences, University of Wales Bangor, Menai Bridge, Anglesey LL59 5EY, UK
}

${ }^{4}$ Present address: Secção de Biologia Marinha, Departamento de Biologia, Universidade dos Açores, Rua da Mãe de Deus, 52, Apartado 1422, 9501-801 Ponta Delgada, São Miguel, Açores, Portugal

\begin{abstract}
Rock pools are dynamic and intermittently isolated habitats in the rocky intertidal. They can be used as model systems to provide a more general insight into the ecology of patchy habitats, which are less amenable to experimentation, such as islands and wildlife reserves. In the present study, a range of pools of differing sizes was selected at 2 vertical levels on the shore to assess the importance of habitat size and shore height on the structure and functioning of rock pool macroalgal communities. Half of these pools were denuded of biota by scraping and chiselling, while the other half were left unmanipulated, to compare the effect of patch size on communities at different successional stages. Pool depth was shown to be markedly more important than area in determining community structure of rock pools, although its effect varied with shore height. The diversity, abundance of some macroalgal morphological groups, and algal gross primary productivity in some circumstances were correlated with pool size, whereas total algal cover generally was not. There was evidence that, even within the same morphological group, species responded differently to the influence of pool size, thus emphasising the importance of species identity when predicting responses to changes in environmental conditions (e.g. temperature stress). This study revealed the importance of pool depth over area in dictating macroalgal community structure, but also highlights the existence of various other effects of rock pool size that were more idiosyncratic.
\end{abstract}

KEY WORDS: Rock pool · Patch size · Shore height · Abiotic factors · Successional stages · Macroalgae $\cdot$ Gross primary productivity

Resale or republication not permitted without written consent of the publisher

\section{INTRODUCTION}

Rock pools are a common feature of rocky shores worldwide. However, compared to studies of emergent rock, these habitats have received much less attention (but see van Tamelen 1996, Underwood \& Skilleter 1996) and little is known about the processes determining the structure of assemblages in them. One possible reason for the lack of work on rock pools is the heterogeneity of this habitat in terms of pool size, shape and assemblage composition (e.g. Astles 1993), which generates difficulties in obtaining appropriate replication for experimental studies (Dethier 1984, Metaxas \& Scheibling 1993, Underwood \& Skilleter 1996).

The effects of physical environmental factors in determining distribution patterns of rocky intertidal assemblages are well known (e.g. Lewis 1964). Physical factors interact with biological factors to determine the distribution of species and structure of assemblages (e.g. Underwood 1980, Benedetti-Cecchi et al. 2000). Over the vertical gradient of the shore increasing physical stress as a result of changes in emersion time has a strong structuring role in assemblage com- 
position. However, height on the shore not only affects the degree of physical harshness, but also the availability of food (e.g. Underwood 1984), the level of predation (e.g. Connell 1970) and the availability of recruits (e.g. Denley \& Underwood 1979).

Organisms within rock pools are continually submerged, and hence are not subject to the same emersion-related stresses as on freely draining rock. As a consequence, rock pools provide refuges for a variety of marine organisms during low tide (Underwood 1980, Underwood \& Jernakoff 1984). Organisms inhabiting rock pools are, nevertheless, subject to stressful environmental conditions during the lowwater period (Ganning 1971, Huggett \& Griffiths 1986), with large fluctuations over short temporal scales in physico-chemical parameters such as temperature, salinity, oxygen, carbon dioxide and $\mathrm{pH}$ (Huggett \& Griffiths 1986). Pools on the upper shore are exposed to longer periods of emersion, and hence experience greater variability in environmental conditions (Huggett \& Griffiths 1986). In addition biota in smaller pools will experience more extreme environmental conditions (e.g. Ganning 1971, Metaxas \& Scheibling 1993, Therriault \& Kolasa 1999), since a lower volume of water is less able to dampen environmental fluctuations during the low-water period. Hence, both height on the shore and pool size may be expected to influence community structure through effects on physico-chemical conditions during low water.

In addition to effects of pool size on physicochemical conditions, size may also influence the likelihood of recruitment. Rock pools form distinct isolated habitats surrounded by a structurally different substratum (Underwood \& Skilleter 1996). Characteristics of habitat patches are important determinants in the organisation of communities and have been studied extensively in marine systems (e.g. Sousa 1985 among others). Both patch size (Keough 1984, Sousa 1984) and patch shape (Airoldi 2003) have been shown to influence patterns of colonisation after disturbance in marine systems (see Sousa 1985 for review). Hence, size of rock pools may also influence community structure by increasing (or decreasing) the potential to sample algal propagules and larvae from the plankton (Sousa 1985), with subsequent effects on the number of species present.

To our knowledge, only 3 previous studies have attempted to relate the size of rock pools to the structure of their communities. Mgaya (1992) found significant effects (although not consistent) of depth and area on the density of rock pool fishes at Helby Island, Canada. Astles (1993) showed few differences in the distribution and abundance of organisms with pool depth in New South Wales, Australia. At the same site,
Underwood \& Skilleter (1996) experimentally examined the effect of pool diameter on sessile organisms, but found no significant patterns.

Complex interactions between biodiversity and abiotic factors influence ecosystem functioning both directly and indirectly (Loreau et al. 2001). Here, we tested the hypothesis that physical conditions, as a consequence of pool size and height on the shore, affect the structure, composition and functioning (measured as gross primary productivity) of rock pools. We also hypothesise that the effect of pool size is especially important in upper-shore rock pools where environmental conditions are more stressful. Furthermore, it is broadly recognised that the usual sequence of colonisation starts with opportunistic species followed by more competitive later colonisers (Dayton 1975). Because this sequence reflects different life strategies and tolerance to environmental stress, it is also expected that assemblages at different successional stages will show contrasting responses to changes in environmental conditions. Therefore, we tested the influence of pool size and shore height in rock pools at different successional stages. Since early successional communities are composed of species with high tolerance to physical stress, we hypothesised that the influence of pool size and shore height would be greater for late-successional assemblages.

\section{MATERIALS AND METHODS}

Study site and community. This work was carried out at 2 moderately exposed rocky shores in the SW of England; Portwrinkle $\left(50^{\circ} 21^{\prime} \mathrm{N}, 4^{\circ} 18^{\prime} \mathrm{W}\right)$ and Looe $\left(50^{\circ} 20^{\prime} \mathrm{N}, 4^{\circ} 28^{\prime} \mathrm{W}\right)$. Shores were chosen owing to the abundance of rock pools of a range of sizes. These shores support similar assemblages of algae and invertebrates, with the mid-shore dominated by barnacles, grazing molluscs, notably Patella vulgata and $P$. depressa and patches of fucoid algae. The upper limit of the barnacle zone is characterised by widespread patches of the lichen Lichina pygmaea, whilst at the lower limit turfing algae (such as Corallina spp., Osmundea spp.) and filamentous green and red algae increase in abundance. On the low shore, Fucus serratus forms an intermittent cover of macroalgal canopy.

Naturally occurring rock pools had similar assemblages at both locations. Corallina spp. were the dominant algae in both upper- and lower-shore pools. On the upper shore, encrusting coralline algae, Bifurcaria bifurcata and the invasive non-native Sargassum muticum were also common. Canopy-forming Fucus serratus and Laminaria digitata were widespread in lower shore pools. Ephemeral algae, such as Ulva spp. and Cladophora spp., as well as red and brown turf- 
forming algae were also present in the majority of pools along the shore, though their relative abundance was low. The patellid limpet Patella ulyssiponensis and the trochids Gibbula umbilicalis and Osilinus lineatus were the most common grazing molluscs in these pools.

Sampling design. Two factors, pool area and pool depth, were examined to determine their effect in rock pool community structure and functioning during early succession. Early succession was initiated through removal of biota and promoted through removal of grazers over the experimental period. Natural pools were utilised in the design so as to encompass the inherent variability found on the shore. Pools showed continuous variation in size parameters; hence, rather than factorial design using distinct size categories, we adopted a regression approach using continuous variation in both area and depth. Two shore heights were selected at each location, 1 toward the upper limit of barnacle distribution ('upper': 3.8 to $4.1 \mathrm{~m}$ above CD [Chart Datum], Portwrinkle; 3.9 to $4.2 \mathrm{~m}$ above CD, Looe) and 1 toward the lower limit ('lower': 1.25 to $2.15 \mathrm{~m}$ above CD, Portwrinkle; 1.5 to $3.0 \mathrm{~m}$ above CD, Looe). At each shore height 25 pools were selected ranging in surface area from 0.03 to $1.9 \mathrm{~m}^{2}$ and in mean depth from 2 to $24 \mathrm{~cm}$. Of these, a subset of 15 was chosen in which the full range of depths was found across the range of pool areas. Pool shape was not taken into consideration, though only pools with well-defined boundaries were selected. Pool dimensions were assessed prior to the start of the experiment. Digital photography was used to determine the surface area, and volume was calculated by pumping out water into containers of known volume.

To initiate succession we cleared 60 pools of biota in February/March 2005, by scraping and chiselling. Erect algae and grazing molluscs were removed, while encrusting algae and the bases of Corallina spp. remained attached to the rock. Throughout the experiment, grazing molluscs, particularly patellid limpets, were excluded by regular manual removal from the pool and the immediate surrounding area. This method successfully reduces grazing intensity to very low levels (S. Jenkins unpubl. data) and avoids the necessity of installing exclusion fences.

Rock pools were routinely sampled at approximately 4 wk intervals for a period of 5 mo (April to August). Percent cover of algae and of major morphological groups (canopy, sub-canopy, turfs, ephemerals and encrusting algae) present in each pool was assessed on each occasion. Macroalgal abundance was assessed in visual estimates of percentage cover using quadrats with 25 subdivisions. Three quadrats were placed randomly in each pool, on each sampling date. Choice of quadrat size varied from 25 to $400 \mathrm{~cm}^{2}$, depending on pool area such that approximately $50 \%$ of pool bottom area was sampled at each visit. Varying quadrat size did not affect the accuracy or precision of abundance estimates (Martins unpubl. data).

At Portwrinkle we used an additional set of pools to compare the relative importance of pool size in structuring the community at different successional stages (early vs. late successional communities). At each shore height, 15 pools were selected in April, with the same characteristics as above. These were left unmanipulated (hereafter referred to as mature pools) and sampled from May onwards.

An estimate of the gross primary productivity of the algal community in pools was made twice (May and August) at Portwrinkle only. Measurements were made based on the 'open system' method described by Kinsey $(1978,1985)$ and used successfully in intertidal rock pools by Nielsen (2001). Such measures allow estimates of community production in a field setting under natural environmental conditions (see 'Discussion' for consideration of the technique utilised). Primary productivity of the benthic algae in each pool was estimated by measuring the change in oxygen concentration (HQ20 Hach Portable LDO, Loveland, USA) both in the light (includes both photosynthesis and community respiration) and in the dark (community respiration only) (see Nielsen 2001). Primary productivity of phytoplankton was negligible $(<1 \%)$ in comparison to benthic algal productivity (G. Martins unpubl. data), and hence was ignored.

The oxygen concentration was measured in all pools within $30 \mathrm{~min}$ after emersion. This reduced the tendency for elevated levels of oxygen to accumulate, and hence reduced problems of oxygen bubble formation. Opaque black polythene was placed over each pool to create artificial darkness for $45 \mathrm{~min}$, after which it was removed and a second oxygen reading taken. A third reading was taken after a period of 45 min of natural light. Oxygen readings were automatically corrected for air pressure. The time period of 45 min was chosen to allow adequate change in oxygen concentration, while preventing very high levels of super-saturation in the light period. Preliminary trials showed that change in oxygen over a 45 min period was linear (S. Jenkins unpubl. data).

Exchange of oxygen between super-saturated pools and air was corrected by using a diffusion constant $\left(K=0.32 \mathrm{~g} \mathrm{~m}^{-2} \mathrm{~h}^{-1}\right)$ calculated for shallow $(<1 \mathrm{~m})$ sheltered water with very limited wave action (see Kinsey 1985 for methodology of correction which accounts for differing water depths). Whilst the use of a cover over pools only during the dark period could modify results by limiting air movement at the pool surface only during this phase and by slight differential heating of water between the periods, trials indicated there was 
no significant difference, whether an optically pure cover was used in the light period or not (S. Jenkins unpubl. data). This was, in part, due to the implementation of measures only on days when wind speed was very light.

Measures of productivity were logistically constrained to be undertaken over 2 consecutive days, although within each day, pools were sampled simultaneously. In both May and August, mean measures of photosynthetically active radiation over the sampling period were similar between the 2 sampling days (May-Day 1: 1390, Day 2: 1560; August-Day 1: 1203, Day 2: 978). The order in which rock pools were sampled was randomly selected so that the source of variation is properly distributed among treatments and it is not a confounding factor in analyses. No significant difference in overall productivity was found between sampling days in either May or August; hence, data were combined for each period.

Gross primary productivity (GPP) per unit area of substratum in each pool was calculated as: GPP per unit area $=[(N+R) \times V] / \mathrm{SA}$, where $N$ is the change in oxygen concentration over the light period (net primary production), $R$ is the change in oxygen concentration over the dark period (respiratory demand), $V$ is pool volume and SA is estimated area of substratum in the pool.

To characterise the temperature regime in pools of differing size and at different shore heights, 5 temperature loggers (Stowaway Tidbit), programmed to record temperature every $15 \mathrm{~min}$, were deployed in pools, over the whole period of study. Three were placed over the full depth range of a deep pool $(0.22 \mathrm{~m}$ deep, $0.63 \mathrm{~m}^{2}$ surface area) on the high shore, and 1 each was placed in a shallow pool on the high shore (0.05 $\mathrm{m}$ deep, $0.35 \mathrm{~m}^{2}$ surface area) and in a shallow pool (0.07 $\mathrm{m}$ deep, $1.05 \mathrm{~m}^{2}$ surface area) on the low shore.

Data analysis. Regression analysis was used to assess the effect of rock pool size on the response variables studied. This analysis was carried out independently for area, mean depth (hereafter referred to as depth) and volume, and was applied separately for each combination of location, shore height and treatment.

Analysis of covariance (ANCOVA) was used to test for effects of shore height on the structure and composition of pool assemblages. Analyses were conducted separately for each location. Area and depth were included as covariates and were log-transformed to improve the linearity of data (Quinn \& Keough 2002). Volume was positively correlated with both area and depth, and was not used in this analysis. Prior to the analysis, heterogeneity of variances was checked using Cochran's test and transformations were applied when necessary (Underwood 1997). In a few cases, heterogeneity of variances was impossible to remove. Nevertheless, Underwood (1997) argues that analysis of variance is robust to departures from this assumption when the number of replicates is high. Additionally, heterogeneity of slopes was tested by crossing both covariates with the other factor(s) and checking for significant interactions (Quinn \& Keough 2002). As suggested by Quinn \& Keough (2002), the analysis of slopes was tested individually for each covariate. When heterogeneity of slopes was detected, the respective covariate was eliminated from the analysis and the ANCOVA performed with the other one alone. Heterogeneity of slopes was never detected for both covariates at the same time. The inclusion of covariates in the analysis increases its power when the relationship between the variable and the covariate is significant (Quinn \& Keough 2002). Where the covariates were not significant, the same general design was tested with an ordinary analysis of variance (ANOVA), using the 15 rock pools as replicates.

Analysis of productivity (conducted at Portwrinkle only) used a 2-way ANCOVA, with shore height and treatment (early and mature pools) as fixed factors, orthogonal with each other.

Lack of independence between sampling times prevented analysis of structure, composition and productivity of pools across time (Underwood 1997). Therefore, all the analyses were performed for each time point separately. The generality of the effect (or lack of it) was then assessed by determining the consistency of the results with time.

Non-metric multidimensional scaling (nMDS) was used to produce 2-dimensional ordinations to compare assemblage structure among shore heights (Clarke 1993). All multivariate analyses were performed on 4th-root-transformed data using Bray-Curtis similarity coefficients (Clarke \& Warwick 2001). The BIOENV procedure (PRIMER-E v5.0, Clarke \& Warwick 2001) was used to assess and distinguish the effect of area and depth on the structure and composition of rock pools. A 1-way nonparametric multivariate analysis of variance (PERMANOVA; Anderson 2001) was used to test hypotheses about algal assemblage structure for each location and treatment. Shore height was used as a fixed factor.

\section{RESULTS}

\section{Early-successional pools}

Monthly removal of limpet grazers reduced but did not eliminate grazing from experimental pools. There was limited recruitment of patellid limpets and continued low-intensity grazing of trochids (Gibbula 
umbilicalis, Osilinus lineatus). However, grazing was reduced to a sufficient level to allow rapid colonisation of algae.

Immediate and dramatic colonisation of scraped rock pools by Ulva spp. within $3 \mathrm{wk}$ followed the start of the experiment and persisted throughout the entire period of the study. A variety of other ephemeral species such as Ceramium spp., Cladophora spp., Scytosiphon lomentaria and Ectocarpus spp. also colonised these pools, but their abundance was low in comparison to Ulva spp. The abundance of perennial species remained low throughout the study period, with the exception of Laminaria digitata, whose cover at the end of the experiment reached nearly $25 \%$ in lower-shore pools at Portwrinkle.

Regression analysis showed that total algal cover was seldom related to pool size (Table 1a). Comparison between shore heights for early successional pools at Portwrinkle showed significantly lower total algal cover on the upper shore in the first 2 mo of succession (April -

Table 1. Regression analyses of: (a) total algal cover and (b) species diversity with pool size on the upper and lower shores. Only significant $r^{2}$ values $(p<0.05)$ are shown. Plus or minus sign indicates whether the slope is positive or negative

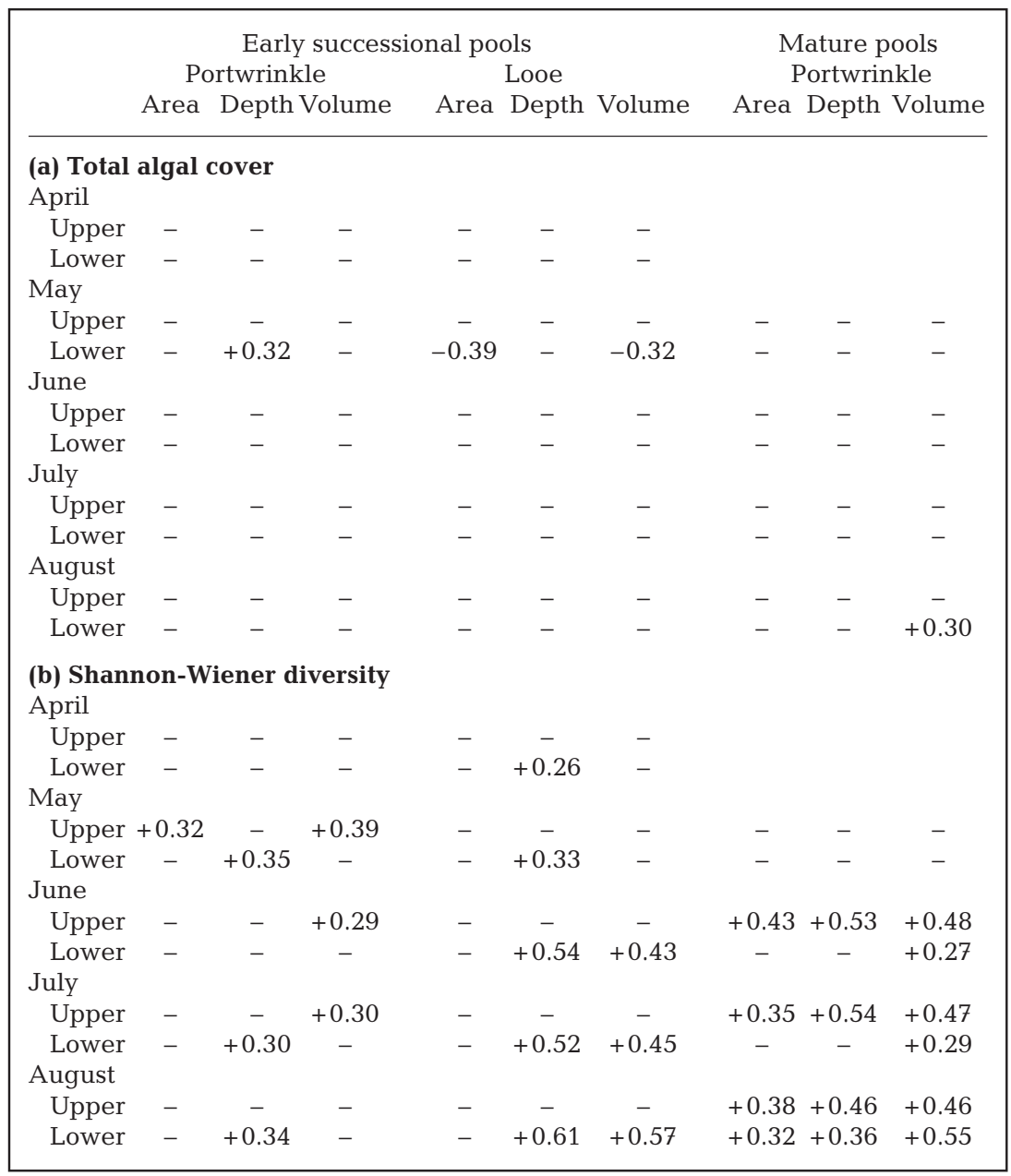

ANOVA on log-transformed data: $F_{1,26}=3.9, \mathrm{p}<0.05$; May-ANOVA: $\left.F_{1,26}=8.9, \mathrm{p}<0.05\right)$. At Looe, no differences in the total algal cover were found between the 2 shore heights throughout the experiment (Fig. 1).

Species diversity increased with pool size (Table 1b). This effect was mostly correlated with depth and volume, but not with area. In early-successional pools there was a significant positive relationship between pool depth and species diversity at both locations on the lower, but not on the upper shore. The effect of volume varied with shore height between the 2 locations, being significant on the upper shore at Portwrinkle and on the lower shore at Looe. There was no consistent trend with time in the degree to which diversity was related to pool size.

Species diversity was consistently higher on the lower compared to the upper shore at Looe, and significantly so on 4 out of the 5 sampling occasions (Fig.1; April-ANCOVA on log-transformed data: $F_{1,26}=$ 13.03, p < 0.01; June-ANCOVA: $F_{1,26}=8.43, \quad \mathrm{p}<0.01 ;$ July ANCOVA: $F_{1,26}=12.28, \mathrm{p}<0.01$; August-ANOVA: $F_{1,28}=10.82, \mathrm{p}<$ 0.01). In contrast, there were no consistent patterns at Portwrinkle, although diversity was significantly greater on the lower shore at the first sampling date (Fig. 1; AprilANOVA: $F_{1,28}=28.25, \mathrm{p}<0.001$ ).

The BIOENV procedure allowed the identification of which measure of size best explained the structure of the assemblage of rock pools. In general, the correlation between pool size and their assemblages was low (Table 2). Nonetheless, depth was unarguably the variable that best explained the structure and composition of earlysuccessional pools, and there seemed to be a trend for an increase in the degree of correlation between size and the composition of pools with time especially at Portwrinkle.

Comparison of the structure of rock pools between shore heights revealed significant differences in the assemblages of early-successional pools on all sampling dates at Portwrinkle, but only twice at Looe (Fig. 2, Table 3). At Portwrinkle, the absence of Laminaria digitata in upper pools was the main reason for differences detected between the 2 levels (SIMPER). The remainder of the assemblage was similar at both 
levels, though the relative abundance of some organisms differed. For example, across all dates, encrusting coralline algae were on average $2.9 \pm 0.4$ times more abundant on the upper shore, whereas Ulva spp. were $1.2 \pm 0.2$ times more abundant in lower-shore pools. At Looe, both the composition and relative abundance of species present was similar on the lower and upper shores. Where differences were detected, these were due to the presence of a greater number of rare species lower on the shore (SIMPER).

\section{Mature pools}

Not surprisingly, communities in mature pools were more diverse than those found in early-successional ones. Mature pools were dominated by Corallina spp.,

\section{Early successional pools}
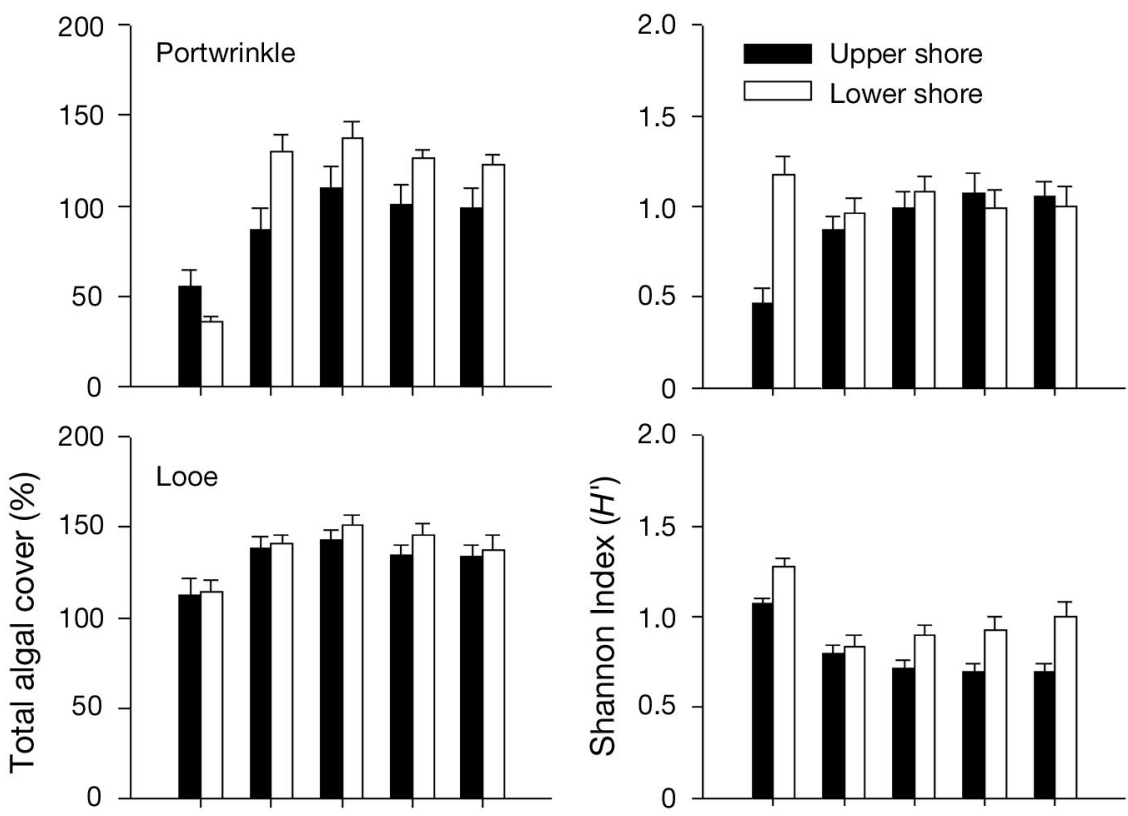

Mature pools
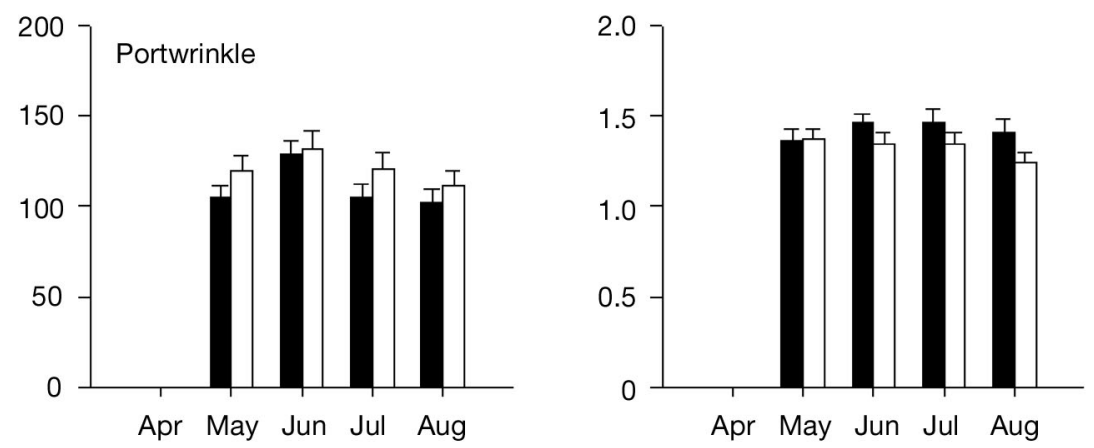

Fig. 1. Mean $( \pm \mathrm{SE}, \mathrm{n}=15)$ total algal cover and species diversity (Shannon index) in early successional and mature pools contributing up to $50 \%$ to the overall total algal cover at both shore heights. Lower on the shore, species such as Laminaria digitata and Fucus serratus were common in these pools, whereas encrusting coralline algae were more common in the upper shore pools.

Total algal cover in mature pools showed no relationship with any measure of pool size (Table 1a) and showed no significant difference between shore heights (Fig. 1). In contrast, species diversity showed a consistent positive relationship with pool size (Table 1). All the measures of size (area, depth and volume) had significant and positive effects on diversity, though depth generally revealed the highest regression coefficients. Volume was an important determinant of diversity both in lower- and upper-shore pools. The effects of area and depth, however, were predominantly found in the upper-shore pools (except in the last month, when significant effects were found at both levels; Table 1b). Species diversity in mature pools did not vary between levels on the shore, except in the last month, when a more diverse community was found on the upper shore. (Fig. 1; August-ANCOVA: $F_{1,26}=6.73$, $\mathrm{p}<0.05)$.

In mature pools, there were significant differences in community structure between shore heights on all sampling dates (Fig. 2, Table 3). The canopy species, Sargassum muticum, Fucus serratus and Laminaria digitata, and encrusting coralline algae explained the major differences found between shore heights (SIMPER). S. muticum was abundant on the upper shore, while F. serratus and $L$. digitata dominated on the lower shore. Together these canopy species accounted for $>30 \%$ of differences between shore heights. Encrusting coralline algae were almost 3 times more abundant on the upper shore and were the 4 th ranked taxa in discriminating between shore heights.

While total algal cover showed no correlation with pool size, individual analyses of algal morphological group cover revealed some significant outcomes (Table 4). On the lower shore, both canopy and ephemeral species showed a consistent relationship with pool depth. However, while canopy cover increased in deeper pools, cover of ephemerals declined. Neither morphological group was related to pool size on the upper shore. Sub-canopy species showed a 
Table 2. BIOENV analyses between different measures of patch size (area, depth, or both) and structure of early successional and mature pools at both shore heights

\begin{tabular}{|c|c|c|c|c|c|}
\hline \multirow[t]{2}{*}{ Location } & \multirow[t]{2}{*}{ Shore height } & \multicolumn{2}{|c|}{ Early } & \multicolumn{2}{|c|}{ Mature } \\
\hline & & Correlation & Variables & Correlation & Variables \\
\hline \multicolumn{6}{|l|}{ April } \\
\hline Portwrinkle & Upper & 0.12 & Both & & \\
\hline Portwrinkle & Lower & 0.11 & Depth & & \\
\hline Looe & Upper & 0.10 & Depth & & \\
\hline Looe & Lower & 0.26 & Depth & & \\
\hline \multicolumn{6}{|l|}{ May } \\
\hline Portwrinkle & Upper & 0.02 & Both & 0.09 & Depth \\
\hline Portwrinkle & Lower & 0.12 & Depth & 0.26 & Depth \\
\hline Looe & Upper & 0.10 & Area & & \\
\hline Looe & Lower & 0.50 & Depth & & \\
\hline \multicolumn{6}{|l|}{ June } \\
\hline Portwrinkle & Upper & 0.18 & Depth & 0.14 & Depth \\
\hline Portwrinkle & Lower & 0.07 & Depth & 0.08 & Area \\
\hline Looe & Upper & 0.12 & Both & & \\
\hline Looe & Lower & 0.40 & Depth & & \\
\hline \multicolumn{6}{|l|}{ July } \\
\hline Portwrinkle & Upper & 0.24 & Both & 0.10 & Depth \\
\hline Portwrinkle & Lower & 0.22 & Depth & 0.16 & Depth \\
\hline Looe & Upper & 0.09 & Depth & & \\
\hline Looe & Lower & 0.34 & Depth & & \\
\hline \multicolumn{6}{|l|}{ August } \\
\hline Portwrinkle & Upper & 0.14 & Depth & 0.10 & Depth \\
\hline Portwrinkle & Lower & 0.40 & Depth & 0.19 & Depth \\
\hline Looe & Upper & 0.09 & Both & & \\
\hline Looe & Lower & 0.41 & Depth & & \\
\hline
\end{tabular}

general increase in cover with area and volume, but not with depth on the upper shore. The cover of turfs and encrusting algae were independent of pool size throughout the study period.

When comparing the abundances of morphological groups at different shore heights, significantly higher abundance of sub-canopy, turfs and encrusting algae were found in upper-shore pools (Fig. 3, Table 5). In contrast, the cover of canopy and ephemeral species were similar at both shore heights.

\section{Productivity}

Gross primary productivity was positively correlated with pool depth (May: $\mathrm{r}^{2}=0.40, \mathrm{p}<0.05$; August: $\mathrm{r}^{2}=$ $0.49, \mathrm{p}<0.05$ ) and volume (April: $\mathrm{r}^{2}=0.30, \mathrm{p}<0.05$; August: $\left.\mathrm{r}^{2}=0.41, \mathrm{p}<0.05\right)$, but not with pool area, in mature pools on the upper shore. No significant regression was obtained in mature pools lower on the shore or in early-successional pools either on the upper or lower shore.

No differences between early and mature pools or shore heights were found in May, although, in August, gross primary productivity was significantly higher in pools lower on the shore (Fig. 4, Table 6).

\section{Temperature}

Temperature loggers revealed contrasting temperature regimes according to the size and location of rock pools (Fig. 5). Comparisons over shore heights showed the upper-shore pool displayed significantly higher daily temperature maxima and daily fluctuations than the lower-shore pool over the whole experimental period (2-way ANOVA: significant effect of shore height $F_{1,240}=12.94, \mathrm{p}<0.01 ; F_{1,90}=$ 4.05 p, $<0.05$; Fig. 5a). Comparisons within a shore height showed that the mid- and bottom layers of the deep pool were significantly cooler and showed lower daily fluctuations than the shallow pool (2-way ANOVA: significant effect of pool $F_{1,240}=125.80$, $\mathrm{p}<0.001 ; F_{1,90}=87.68, \mathrm{p}<0.001$; $F_{1,240}=44.65, \mathrm{p}<0.001 ; F_{1,90}=39.86$, $\mathrm{p}<0.001$; Fig 5b), but stratification of the water in the deep pool meant the surface layer was very similar and showed no significant difference to that in the shallow pool $\left(F_{1,240}=0.03\right.$, $\left.\mathrm{p}>0.8 ; F_{1,90}=0.23, \mathrm{p}>0.6\right)$.

\section{DISCUSSION}

A growing body of literature has emphasised the role of patch size in structuring marine systems (e.g. Keough 1984, Sousa 1984). Rock pools create obvious patches in intertidal assemblages through modification of environmental conditions during low-water periods. Like other patches in nature, pools may be described on the basis of their area, perimeter and shape. An additional descriptor unique to pools is their depth, which, combined with area, will dictate the volume of water held. This study showed that depth was more important than area in explaining species diversity and community composition in both early successional and mature pools. The lack of influence of area on the abundance of organisms in pools is in agreement with the work of Underwood \& Skilleter (1996), who found little evidence that diameter (a surrogate for area) of rock pools leads to significant differences in the abundance of most taxa. These results suggest that more stable environmental conditions or greater niche diversity in larger pools are more likely to contribute to changes in assemblage composition with pool size rather than an increased ability to sample algal and larval propagules in pools with a larger area. 

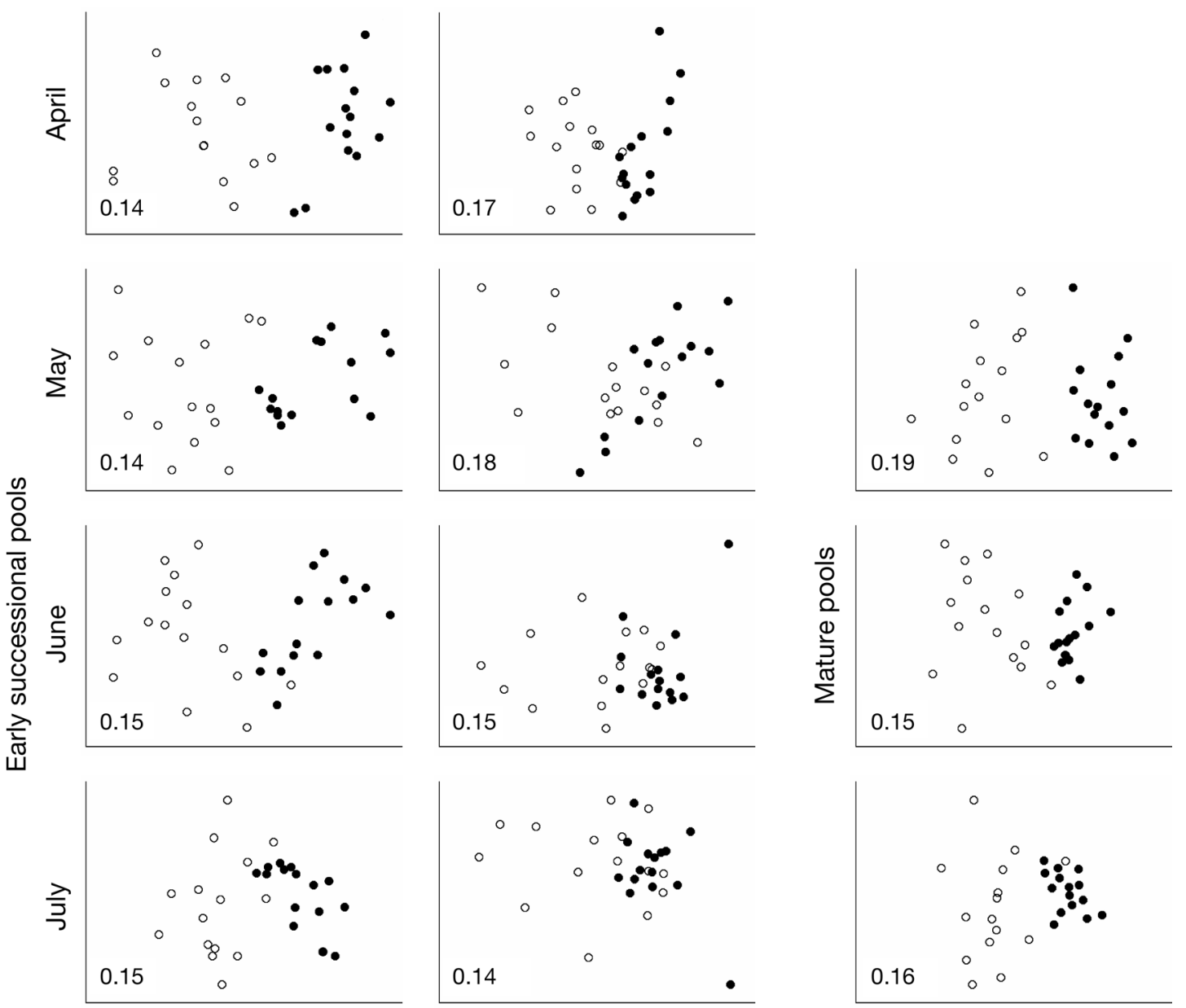

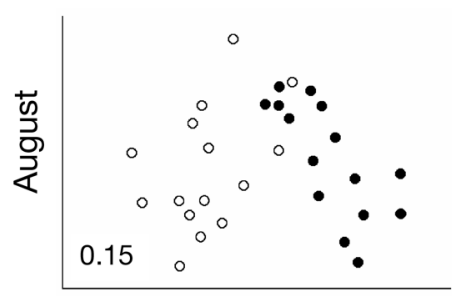

Portwrinkle
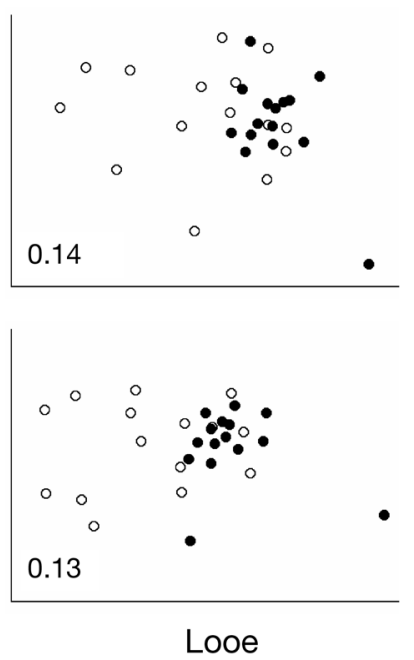
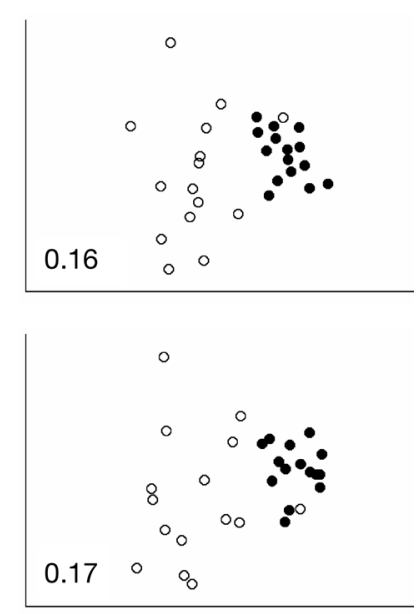

Portwrinkle

Fig. 2. Non-metric multidimensional scaling ordination of the structure of early successional and mature pools. Filled and open circles represent pools on the upper and lower shore, respectively. Note stress values are given for each graph

Although the volume of water held in large, shallow pools can equal that of small, deep ones, surface area exposed to the air is greater in the former, leading to higher rates of energy exchange between air and water. Thus, rock pools with greater surface area/ depth ratios (i.e. shallow pools) tend to experience larger fluctuations in physico-chemical parameters (e.g. temperature, oxygen concentration, pH) (Ganning 1971, Metaxas \& Scheibling 1993). Whilst not the main focus of the work, our basic temperature data based on unreplicated pools indicate that deep pools have more stable conditions than shallow pools. The main body of water (in deep and mid-layers) showed less variation over a short temporal scale than in shallow pools. However, there was strong thermal stratification in the deep pool monitored; maximum temperature in the surface layer equalled that of the shallow pool at the same shore height. Such stratification of temperature (and probably of other physico-chemical parameters as well) in deep pools supports the idea that these pools may support a more diverse community by creating more niches. Under this scenario, 
Table 3. PERMANOVA comparing the structure and composition of early successional and mature pools on the upper and lower shore. Bold F-values indicate significant p-values $\left({ }^{*} \mathrm{p}<0.05,{ }^{* *} \mathrm{p}<0.01,{ }^{* * *} \mathrm{p}<0.001\right)$

\begin{tabular}{|c|c|c|c|c|c|c|}
\hline \multirow[b]{2}{*}{$\begin{array}{l}\text { Source } \\
\text { df }\end{array}$} & \multicolumn{4}{|c|}{ - Early successional pools } & \multicolumn{2}{|c|}{$\begin{array}{l}\text { Mature pools } \\
\text { Portwrinkle }\end{array}$} \\
\hline & $\begin{array}{c}\text { Shore height } \\
1\end{array}$ & $\begin{array}{c}\text { Residual } \\
28\end{array}$ & $\begin{array}{c}\text { Shore height } \\
1\end{array}$ & $\begin{array}{l}\text { Residual } \\
28\end{array}$ & $\begin{array}{c}\text { Shore height } \\
1\end{array}$ & $\begin{array}{c}\text { Residual } \\
28\end{array}$ \\
\hline \multicolumn{7}{|l|}{ April } \\
\hline $\mathrm{MS}$ & 10666.30 & 1323.35 & 259.11 & 882.69 & & \\
\hline$F$ & $8.06^{* * *}$ & & 0.29 & & & \\
\hline \multicolumn{7}{|l|}{ May } \\
\hline MS & 5040.78 & 1235.03 & 1996.67 & 662.83 & 10090.38 & 1280.77 \\
\hline$F$ & $4.08^{* * *}$ & & $3.01^{*}$ & & $7.88^{* * *}$ & \\
\hline \multicolumn{7}{|l|}{ June } \\
\hline MS & 5385.05 & 930.78 & 1572.93 & 814.01 & 8308.94 & 1647.42 \\
\hline$F$ & $5.79^{* * *}$ & & 1.93 & & $5.04^{* * *}$ & \\
\hline \multicolumn{7}{|l|}{ July } \\
\hline MS & 5705.92 & 1176.18 & 1074.66 & 761.86 & 8516.41 & 1569.71 \\
\hline$F$ & $4.85^{* *}$ & & 1.41 & & $5.43^{* * *}$ & \\
\hline \multicolumn{7}{|l|}{ August } \\
\hline MS & 5399.02 & 1357.66 & 3319.04 & 911.30 & 8298.80 & 1452.77 \\
\hline$F$ & $3.98^{* *}$ & & $3.64^{* *}$ & & $5.71^{* * *}$ & \\
\hline
\end{tabular}

groups of stress-tolerant species could colonise the upper layers of pools, whereas groups of less stresstolerant species could colonise the mid- and lower levels. This idea is supported by van Tamelen (1996), who found a persistent pattern of algal zonation in rock pools. However, further work is needed to test these ideas.

Height above low water is an important structuring force for rocky intertidal communities (Underwood \& Denley 1984). Our results show consistent differences in the assemblages in rock pools at different heights in most analyses. We hypothesised that the role of pool size in influencing community structure and functioning of pools would be greater on the upper shore, where environmental conditions are harsher. In early successional pools, there was little support for this hypothesis. Early successional assemblages were composed of fast-growing foliose species, such as Ulva spp., which show relatively high tolerance toward environmental stress (e.g. Steneck \& Dethier 1994). This could explain the lack of influence of pool size on the upper shore. In mature pools, however, all 3 measures of size had a positive influence on species diversity, mostly on the upper shore (though volume was

Table 4. Regression analyses between percent cover of morphological groups and pool size on the upper and lower shore pools (Portwrinkle mature pools only). Interpretation as in Table 1

\begin{tabular}{|c|c|c|c|c|c|c|c|c|c|c|}
\hline & \multicolumn{2}{|c|}{ Canopy } & \multicolumn{2}{|c|}{ Sub-canopy } & \multicolumn{2}{|c|}{ Turf } & \multicolumn{2}{|c|}{ Ephemerals } & \multicolumn{2}{|c|}{ Encrusting algae } \\
\hline & Upper & Lower & Upper & Lower & Upper & Lower & Upper & Lower & Upper & Lower \\
\hline \multicolumn{11}{|l|}{ May } \\
\hline Area & - & - & +0.31 & - & - & - & - & - & - & - \\
\hline Depth & - & +0.35 & - & - & - & - & - & -0.36 & - & - \\
\hline Volume & - & - & - & - & - & - & - & - & - & - \\
\hline \multicolumn{11}{|l|}{ June } \\
\hline Area & - & - & +0.44 & - & - & - & - & - & - & - \\
\hline Depth & - & - & - & - & - & - & - & -0.53 & - & - \\
\hline Volume & - & - & +0.40 & - & - & - & - & - & - & - \\
\hline \multicolumn{11}{|l|}{ July } \\
\hline Area & - & - & +0.43 & - & - & - & - & - & - & - \\
\hline Depth & - & +0.36 & - & - & - & - & - & -0.27 & - & - \\
\hline Volume & - & - & +0.34 & - & - & - & - & - & - & - \\
\hline \multicolumn{11}{|l|}{ August } \\
\hline Area & - & - & +0.30 & - & - & - & - & - & - & - \\
\hline Depth & - & +0.29 & - & - & - & - & - & -0.39 & -0.35 & - \\
\hline Volume & - & - & - & - & - & - & - & - & - & - \\
\hline
\end{tabular}



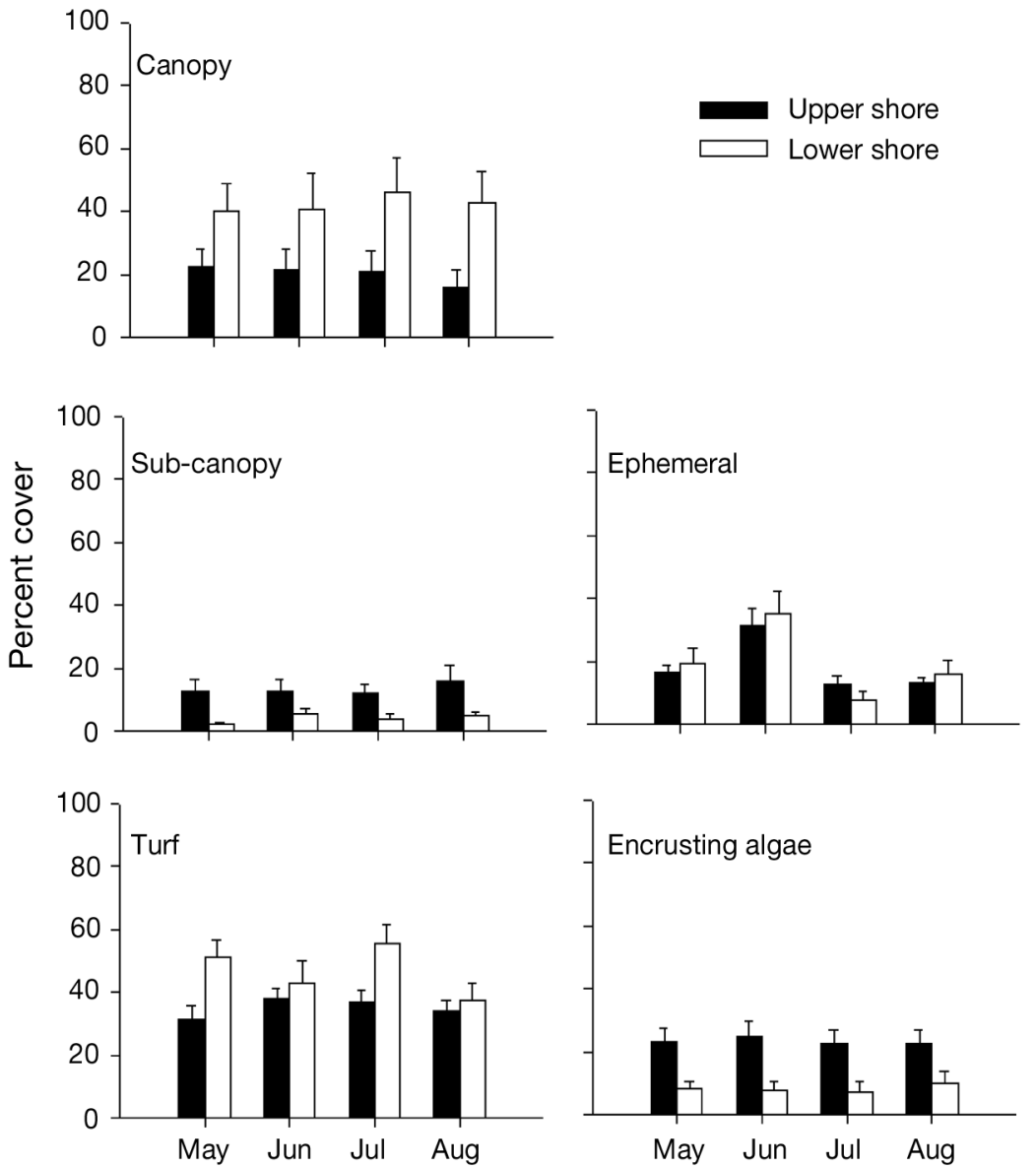

Fig. 3. Mean $( \pm \mathrm{SE}, \mathrm{n}=15)$ percent cover of morphological groups in mature pools at Portwrinkle on the upper and lower shores equally important lower on the shore). Thus, mature pools showed some support for the hypothesis of a greater influence of pool size on community structure on the upper shore.

Although pool size had little or no effect on total algal abundance, the cover of different macroalgal morphological groups revealed idiosyncratic responses to changes in size. While the abundance of some morphological groups (turfs and encrusting algae) was seldom related to changes in pool size, others were positively (canopy and sub-canopy) or negatively (ephemerals) associated. Encrusting algae, and to some extent algal turfs, are stress-tolerant species (Steneck \& Dethier 1994). This could explain the lack of response of their abundance to variations in pool size. Canopy cover was positively influenced by depth in the lowershore pools only. The lack of influence on the upper shore may be attributable to the differences in species composition of this group and respective tolerance to environmental fluctuations. Fucus serratus and Laminaria digitata were the main canopy species in low-shore, mature pools, whilst Sargassum muticum, a species with a broad tolerance for irradiance, salinity and temperature (Norton 1977), was the most abundant canopy species in the upper-shore pools. The cause of the negative relationship

Table 5. ANCOVA comparing percent cover of macroalgae morphological groups in rock pools on the upper and lower shore (Portwrinkle mature pools only); p-values as in Table 3 (n.s.: covariates were not significant and ANOVA was used instead. The residual degrees of freedom in ANOVA are 28)

\begin{tabular}{|c|c|c|c|c|c|c|c|c|c|}
\hline \multirow[b]{2}{*}{ Source } & \multirow[b]{2}{*}{$\mathrm{df}$} & \multicolumn{2}{|c|}{ May } & \multicolumn{2}{|c|}{ Jun } & \multicolumn{2}{|c|}{ Jul } & \multicolumn{2}{|c|}{ Aug } \\
\hline & & MS & $F$ & MS & $F$ & MS & $F$ & MS & $F$ \\
\hline \multicolumn{10}{|l|}{ Canopy } \\
\hline Shore Height & 1 & 1877.60 & 2.68 & 9.51 & 0.89 & 3491.00 & 3.40 & 24.73 & 2.76 \\
\hline \multirow[t]{2}{*}{ Residual } & 26 & 700.30 & & 10.63 & & 1027.00 & & 8.97 & \\
\hline & & \multicolumn{4}{|c|}{ SqRt } & & & \multicolumn{2}{|c|}{ SqRt } \\
\hline \multicolumn{2}{|l|}{ Sub-canopy } & & \multirow{3}{*}{$5.03^{*}$} & & & & & & \\
\hline Shore height & 1 & 8.85 & & 7.33 & 2.04 & 0.97 & $4.65^{*}$ & 0.69 & 2.44 \\
\hline \multirow[t]{2}{*}{ Residual } & 26 & & & 3.59 & & 0.20 & & 0.28 & \\
\hline & & \multicolumn{2}{|c|}{ n.s., $\log (x+1)$} & \multicolumn{2}{|c|}{ n.s., SqRt } & \multicolumn{2}{|c|}{$\log (x+1)$} & \multicolumn{2}{|c|}{ n.s., $\log (x+1)$} \\
\hline \multicolumn{2}{|l|}{ Turf } & & & & & & & & \\
\hline Shore height & 1 & 3011.70 & \multirow[t]{2}{*}{$8.61^{* *}$} & 192.10 & 0.41 & 2536.10 & $5.78^{*}$ & 103.30 & 0.36 \\
\hline \multirow[t]{2}{*}{ Residual } & 26 & 349.60 & & 471.60 & & 438.80 & & 290.20 & \\
\hline & & \multicolumn{2}{|c|}{ n.s. } & \multicolumn{2}{|c|}{ n.s., heterogenous } & \multicolumn{2}{|c|}{ n.s. } & \multicolumn{2}{|c|}{ n.s. } \\
\hline Shore height & 1 & 0.03 & \multirow[t]{2}{*}{0.01} & \multirow{2}{*}{$\begin{array}{c}63.60 \\
464.10\end{array}$} & \multirow[t]{2}{*}{0.14} & 198.50 & \multirow[t]{2}{*}{1.71} & 62.30 & \multirow[t]{2}{*}{0.35} \\
\hline \multirow[t]{2}{*}{ Residual } & 26 & 3.33 & & & & 116.30 & & 177.80 & \\
\hline & & \multicolumn{2}{|c|}{ n.s., SqRt } & \multicolumn{2}{|c|}{ n.s. } & \multicolumn{2}{|c|}{ n.s. } & n.s., heter & eneous \\
\hline Shore height & 1 & 19.96 & $4.66^{*}$ & 29.12 & $7.28^{*}$ & 1697.50 & $7.91^{* *}$ & 1244.30 & $4.59^{*}$ \\
\hline Residual & 26 & 4.28 & & 4.00 & & 214.60 & & 271.20 & \\
\hline & & n.s., & & & & $\mathrm{n}$ & & & \\
\hline
\end{tabular}




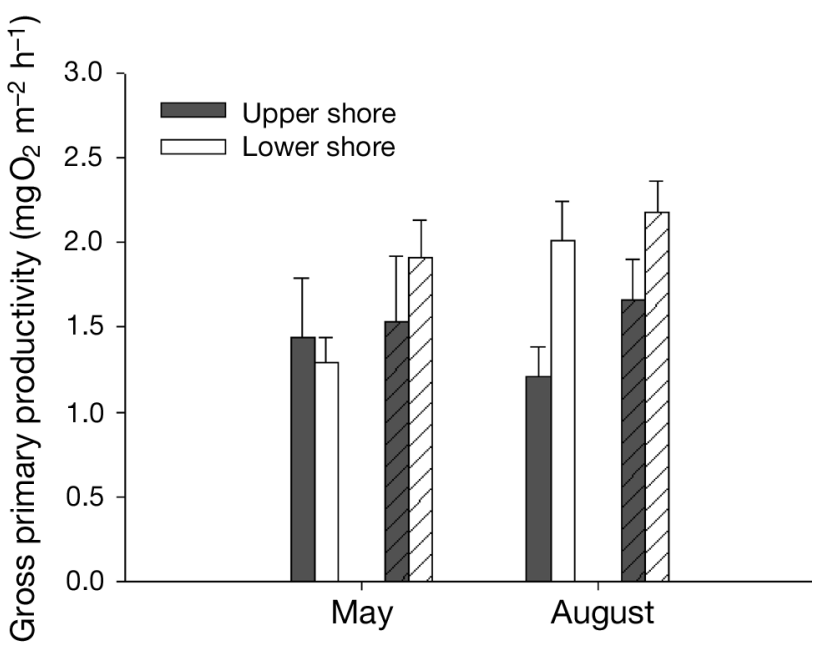

Fig. 4. Mean $( \pm \mathrm{SE})$ gross primary productivity of mature (open bars) and early successional (striped bars) pools on the upper and lower shore at Portwrinkle in May $(\mathrm{n}=11)$ and August $(\mathrm{n}=12)$

between depth and cover of ephemeral species is unclear. These species have high tolerance to physical harshness, but may be out-competed in more benign environments (large pools) by perennial canopy species. Thus, increasing pool size may promote the growth of competitively superior species, which, in turn, may have a negative influence on competitively inferior species (Keough 1984).

Much effort has been made recently to understand the link between biodiversity, environment and ecosystem functioning (see Loreau et al. 2001 for review). The study of open natural systems allows estimation of total community productivity in situ. There are many advantages in this approach in terms of understanding patterns under natural environmental conditions, rather than some simulated analogue, but there are clearly also disadvantages, namely a reduction in analytical precision. These problems are considered in detail by Kinsey $(1978,1985)$. In many ways small, shallow, enclosed bodies of water with naturally high levels of metabolic activity such as rock pools are the ideal environment in which to conduct measures of natural productivity. The main confounding factor in such measures is that departures in the dissolved oxygen concentration from that which is in atmospheric equilibrium will result in gas
Table 6. ANOVA comparing macroalgal productivity in both treatments (early and mature) in upper- and lower-shore pools ( $p$-values as in Table 3 ). Covariates were never significant on either date. Within each sampling date, the number of pools sampled was not the same (owing to logistical constraints). Data were randomly dropped to produce balanced data for each date of the analyses, hence the different degrees of freedom for each month

\begin{tabular}{|lcccccc|}
\hline & \multicolumn{4}{c}{ May } & \multicolumn{3}{c|}{ Aug } \\
Source & df & MS & $F$ & df & MS & $F$ \\
\hline Shore height (Sh) & 1 & 0.03 & 0.03 & 1 & 5.20 & $\mathbf{1 0 . 1 8}^{* *}$ \\
Treatment (Tr) & 1 & 0.15 & 0.17 & 1 & 1.14 & 2.23 \\
Sh $\times \operatorname{Tr}$ & 1 & 1.27 & 1.43 & 1 & 0.25 & 0.49 \\
Residual & 40 & 0.89 & & 44 & 0.51 & \\
\hline
\end{tabular}

diffusion to/from the water body. Fortunately, in the short term (minutes or hours), such exchange of oxygen is likely to be small relative to the level of production (Kinsey 1985), especially in small undisturbed bodies of water with highly productive communities. Our approach like that of Nielsen (2001) was to compare among shore heights and treatments; hence, measures of production should be viewed, at the very least, as a useful index of total production in pools to compare among pool sizes and, at the most, as a reasonable estimate of total production in rock pools.
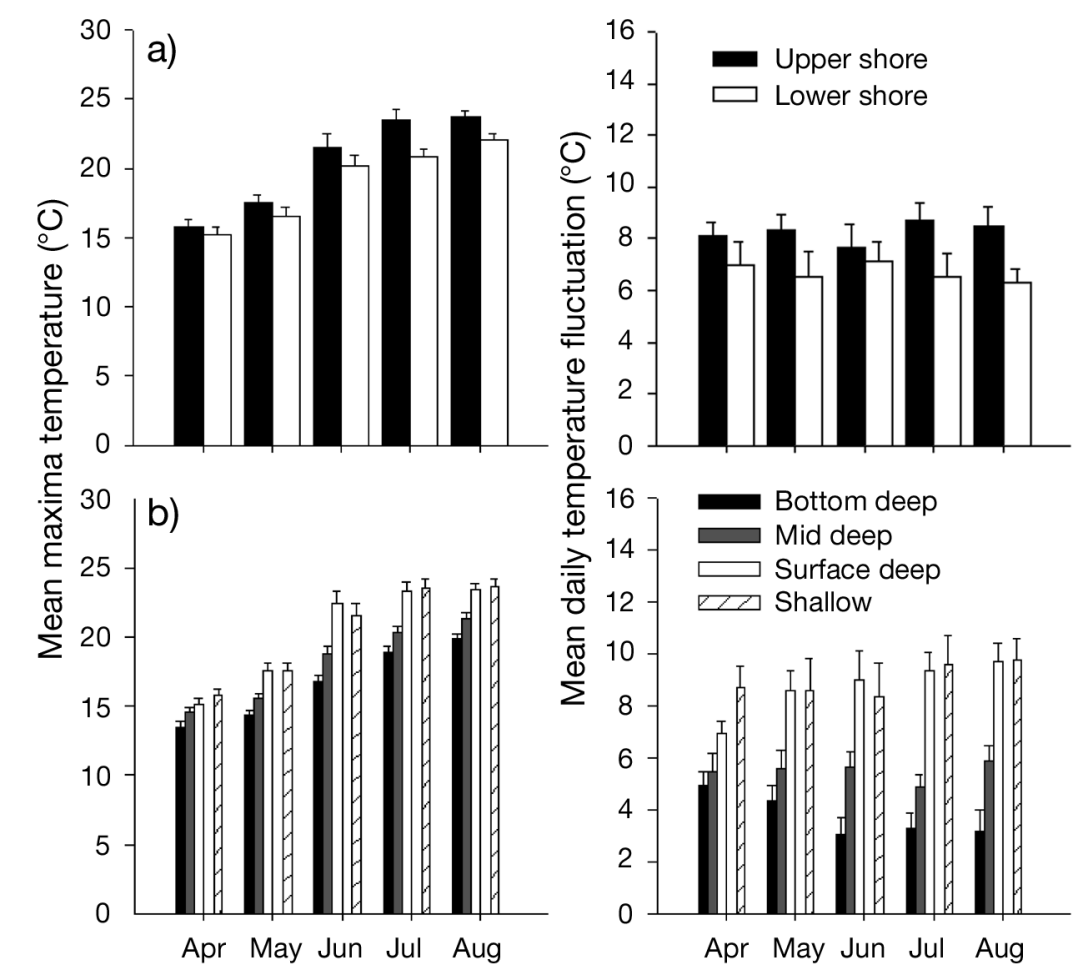

Fig. 5. Mean ( \pm SE) maxima temperatures (left panels) and daily temperature fluctuations (right panels) in rock pools comparing: (a) a pool on the upper and lower shore and (b) a deep pool (with 3 monitored depths) and a shallow pool (both on the upper shore) 
In our study, pool size and, specifically, depth and volume positively influenced gross productivity in upper-shore, mature pools. In these same pools, diversity was positively correlated with the same morphometric variables. However, lower on the shore and in all early-successional pools no correlation was found. The link between pool size and productivity only on the upper shore implies that only under stressful conditions does pool size influence the functioning of these habitats, possibly by ameliorating environmental conditions. Comparison between communities in different stages of succession showed that despite the large differences in the structure of mature and earlysuccessional species, gross primary productivity was similar in both assemblages. Early-successional assemblages consisted mainly of foliose green algae, which are highly productive species (Larsson et al. 1997). This could, therefore, compensate for the low biomass of these assemblages compared to mature communities.

In summary, this study showed the idiosyncratic effects of size on the distribution and abundance of organisms in rock pools. Pool size (especially depth) influenced gross primary productivity only in stressful environments. Although pool size was a contributory factor to assemblage composition and functioning, it only explained a relatively small proportion of the variability found, supporting the general idea that rock pools are highly dynamic habitats and suggesting the interplay of numerous physical and biological factors in structuring rock pool communities.

Acknowledgements. This research was conducted in partial fulfilment of a MRes in Marine Biology degree by G.M.M. and funded by Fundação para a Ciência e Tecnologia (FCT) SFRH/BM/16100/2004 and the NERC Standard Grant NE/B504649/1. This research also benefitted from collaboration within the Marine Biodiversity and Ecosystem Functioning (MarBEF) network. The authors are grateful to all of those who helped during fieldwork, but especially to J. Griffin, A. Silva, P. Masterson, M. Lilley and L. Noël for helping with seaweed identification. The experiments comply with the laws of the country in which they were performed. The present paper greatly benefited from the comments of 3 anonymous referees.

\section{LITERATURE CITED}

Airoldi L (2003) Effects of patch shape in intertidal algal mosaics: roles of area, perimeter and distance from edge. Mar Biol 143:639-650

Anderson MJ (2001) A new method for non-parametric multivariate analysis of variance. Aust Ecol 26:32-46

Astles KL (1993) Patterns of abundance and distribution of species in intertidal rock pools. J Mar Biol Assoc UK 73: 555-569

Benedetti-Cecchi L, Bulleri F, Cinelli F (2000) The interplay of physical and biological factors in maintaining mid-shore and low-shore assemblages on rocky coasts in the northwest Mediterranean. Oecologia 123:406-417

Clarke KR (1993) Nonparametric multivariate analyses of changes in community structure. Aust J Ecol 18:117-143

Clarke KR, Warwick RM (2001) Change in marine communities: an approach to statistical analysis and interpretation, 2nd edn. PRIMER-E, Plymouth

Connell JH (1970) A predator-prey system in the marine intertidal region. I. Balanus glandula and several predatory species of Thais. Ecol Monogr 40:4978

Dayton PK (1975) Experimental evaluation of ecological dominance in a rocky intertidal algal community. Ecol Monogr 45:137-159

Denley EJ, Underwood AJ (1979) Experiments on factors influencing settlement, survival and growth of two species of barnacles in New South Wales. J Exp Mar Biol Ecol 36: 269-293

Dethier MN (1984) Disturbance and recovery in intertidal pools: maintenance of mosaic patterns. Ecol Monogr 54:99-118

Ganning B (1971) Studies on chemical, physical and biological conditions in Swedish rockpool ecosystems. Ophelia 9: 51-105

Huggett J, Griffiths CL (1986) Some relationships between elevation, physicochemical variables and biota of intertidal rock pools. Mar Ecol Prog Ser 29:189-197

Keough MJ (1984) Effects of patch size on the abundance of sessile marine invertebrates. Ecology 65:423-437

Kinsey DW (1978) Productivity and calcification estimates using slack-water periods and field enclosures. In: Stoddart DR, Johannes RE (eds) Coral reefs: research methods. United Nations Educational Scientific and Cultural Organization, Norwich, p 439-467

Kinsey DW (1985) Ecological energetics: open-flow systems. In: Littler MM, Littler DS (eds) Ecological field methods: macroalgae. Phycological Society of America handbook of phycological methods, Vol 4. Cambridge University Press, p 427-460

Larsson C, Axelsson L, Ryberg H, Beer S (1997) Photosynthetic carbon utilization by Enteromorpha intestinalis (Chlorophyta) from a Swedish rockpool. Eur J Phycol 32: $49-54$

Lewis JR (1964) The ecology of rocky shores. English Universities Press, London

Loreau M, Naeem S, Inchausti $\mathrm{P}$, Bengtsson $\mathrm{J}$ and 8 others (2001) Biodiversity and ecosystem functioning: current knowledge and future challenges. Science 294:804-808

Metaxas A, Scheibling RE (1993) Community structure and organization of tidepools. Mar Ecol Prog Ser 98:187-198

Mgaya YD (1992) Density and production of Clinocottus globiceps and Oligocottus maculosus (Cottidae) in tide pools at Helby Island, British Columbia. Mar Ecol Prog Ser 85: 219-225

Nielsen KJ (2001) Bottom-up and top-down forces in tide pools: test of a food chain model in an intertidal community. Ecol Monogr 71:187-217

Norton TA (1977) The growth and development of Sargassum muticum (Yendo) Fensholt. J Exp Mar Biol Ecol 26:41-53

Quinn GP, Keough MJ (2002) Experimental design and data analysis for biologists. Cambridge University Press, Cambridge

Sousa WP (1984) Intertidal mosaics: patch size, propagules availability, and spatially variable patterns of succession. Ecology 65:1918-1935

Sousa WP (1985) Disturbance and patch dynamics on rocky intertidal shores. In: Pickett STA, White PS (eds) The ecology of natural disturbance and patch dynamics. Academic Press, London, p 101-124 
Steneck RS, Dethier MN (1994) A functional group approach to the structure of algal-dominated communities. Oikos 69:476-498

Therriault TW, Kolasa J (1999) Physical determinants of richness, diversity, evenness and abundance in natural aquatic microcosms. Hydrobiologia 412:123-130

Underwood AJ (1980) The effects of grazing by gastropods and physical factors on the upper limits of distribution of intertidal macroalgae. Oecologia 46:201213

Underwood AJ (1984) Vertical and seasonal patterns in competition for microalgae between intertidal gastropods. Oecologia 64:211-222

Underwood AJ (1997) Experiments in ecology: their logical design and interpretation using analysis of variance. Cambridge University Press, Cambridge

Underwood AJ, Denley J (1984) Paradigms, explanations, and

Editorial responsibility: Howard Browman (Associate Editorin-Chief), Storebø, Norway generalizations in models for the structure of intertidal communities on rocky shores. In: Strong DR, Simberloff D, Abele LG, Thistke AB (eds) Ecological communities: conceptual issues and the evidence. Princeton University, Princeton, NJ, p 151-180

Underwood AJ, Jernakoff P (1984) The effects of tidal height, wave exposure, seasonality and rock-pools on grazing and the disturbance on intertidal macroalgae in New South Wales, Australia. J Exp Mar Biol Ecol 75: 71-96

Underwood AJ, Skilleter GA (1996) Effects of patch-size on the structure of assemblages in rock pools. J Exp Mar Biol Ecol 197:63-90

van Tamelen PG (1996) Algal zonation in tidepools: experimental evaluation of the roles of physical disturbance, herbivory and competition. J Exp Mar Biol Ecol 201:197-231

Submitted: November 29, 2005; Accepted: May 1, 2006 Proofs received from author(s): December 4, 2006 